Revista Universo Contábil, ISSN 1809-3337

FURB, v. 5, n.3, p. 60-81, jul./set., 2009

doi:10.4270/ruc.2009322

Disponível em www.furb.br/universocontabil

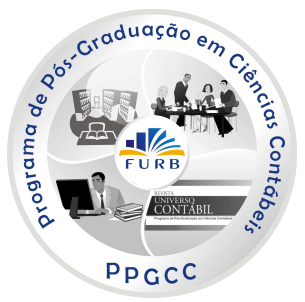

\title{
FONTES DIFERENCIADAS DE FINANCIAMENTO: IMPACTO NA ESTRUTURA DE CAPITAL DE USINAS BRASILEIRAS DE AÇÚCAR E ÁLCOOL1
}

\section{DIFFERENTIATED FINANCING SOURCES: THE IMPACT ON THE CAPITAL STRUCTURE OF BRAZILIAN SUGAR AND ALCOHOL COMPANIES}

\author{
Tatiana Albanez \\ Doutoranda do Programa de Pós-Graduação em Ciências Contábeis da FEA/USP \\ Endereço: Av. Professor Luciano Gualberto, 908 - FEA3 - Cidade Universitária \\ CEP: 05508-900 - São Paulo/SP - Brasil \\ E-mail: tatiana.albanez@usp.br \\ Telefone: (11) 3091-5862 \\ Maurício Ribeiro do Valle \\ Professor do Departamento de Contabilidade da FEA-RP/USP \\ Livre-Docente em Controladoria e Contabilidade pela Universidade de São Paulo \\ Doutor em Controladoria e Contabilidade pela Universidade de São Paulo \\ Endereço: Av. dos Bandeirantes, 3900 - Monte Alegre \\ CEP: 14040-900 - Ribeirão Preto/SP - Brasil \\ E-mail: marvalle@usp.br \\ Telefone: (16) 3602-3942
}

\section{RESUMO}

Este artigo analisa a composição do endividamento de usinas de açúcar e álcool da região centro-sul do país em cinco anos-safra (01/02, 02/03, 03/04, 04/05 e 05/06). Procura-se incorporar fatores institucionais à análise da estrutura de capital das empresas, como o acesso a diferentes fontes de recursos, bem como conhecer qual a importância desses recursos na estrutura de capital das usinas analisadas. Para tanto, busca-se conhecer qual a participação no endividamento das diferentes linhas de financiamento utilizadas pelas usinas, as quais são agrupadas em quatro categorias: linhas diferenciadas em moeda nacional, linhas diferenciadas em moeda estrangeira, linhas de mercado em moeda nacional e linhas de

\footnotetext{
1 Artigo recebido em 23.07.2008. Revisado por pares em 03.12.2008. Reformulado em 06.03.2009. Recomendado em 13.03.2009 por Ilse Maria Beuren (Editora). Publicado em 30.09.2009. Organização responsável pelo periódico: FURB.
} 
mercado em moeda estrangeira. A pesquisa também procura identificar se as usinas utilizaram, no período analisado, as estratégias de baixo endividamento e/ou alta liquidez para compensar as altas taxas de juros a que estavam sujeitas no mercado financeiro nacional. A amostra utilizada é composta por 35 usinas que processam aproximadamente $33 \%$ de toda a cana moída no país. Como principais resultados apontam-se que as usinas utilizaram principalmente recursos provenientes de linhas diferenciadas em moeda nacional e de linhas de mercado em moeda estrangeira. Verifica-se também que, em média, as usinas apresentaram um nível de endividamento em torno de 30\%, prevalecendo a captação de recursos de longo prazo, e altos níveis de liquidez ao longo do período. Nota-se que o acesso a linhas diferenciadas de financiamento influenciou as decisões de captação de recursos tomadas pelas usinas, visto que a utilização destas linhas prevaleceu em todos os anos, o que ratifica a importância da inclusão de fatores institucionais na análise da estrutura de capital das empresas.

Palavras-chave: Setor sucroalcooleiro. Estrutura de capital. Linhas de financiamento. Fatores institucionais.

\section{ABSTRACT}

This paper analyzes the debt composition of sugar and ethanol companies from the centersouth area of the country in five year-harvest (01/02, 02/03, 03/04, 04/05 and 05/06). It is tried to incorporate institutional factors to the capital structure analysis of the companies, such as the access to different sources, as well as to know the importance of those resources in the capital structure of the analyzed companies. Thus, it is tried to understand the participation of different financing lines used by the firms in their indebtedness, which are grouped in four categories: differentiated lines in national currency, differentiated lines in foreign currency, market lines in national currency and market lines in foreign currency. The research also tries to identify whether the companies used, in the analyzed period, the strategies of low debt and/or high liquidity to compensate the high interest rates of the national market. The sample is composed by 35 companies that process around $33 \%$ of the sugar cane of the country. The main results showed that the companies used mainly resources from differentiated lines in national currency and from market lines in foreign currency. It is also verified that, on average, the companies presented a debt level around 30\%, in which prevails the use of long-term debt, and high liquidity levels through the period. It is noticed that the access to differentiated financing lines have influenced the financing decisions taken by the companies, since the use of these lines prevailed in all of the years, which ratifies the importance of including institutional factors in the capital structure analysis of the companies.

Keywords: Sugar and ethanol sector. Capital structure. Financing lines. Institutional factors.

\section{INTRODUÇÃO}

Vários estudos relativos à estrutura de capital (MYERS, 1977; TITMAN e WESSELS, 1988; BARCLAY e SMITH JR., 1995; STOHS e MAUER, 1996; GUEDES e OPLER, 1996) buscaram explicar o mix de fontes de financiamento utilizado pelas empresas para financiar seus investimentos, ou seja, quais os determinantes para a escolha de diferentes formas de captação. Não há uma única teoria capaz de explicar como esta escolha é realizada, mas as teorias existentes focam diferentes aspectos, como impostos, custos de falência ou reorganização, custos de agência e assimetria de informações, e evidenciam os custos e 
benefícios de diferentes alternativas de financiamento.

No entanto, a maior parte dos estudos desenvolvidos nesta linha é realizada em economias desenvolvidas, o que coloca em dúvida a aplicação de suas bases teóricas e metodológicas para estudar países em desenvolvimento. Em trabalho que tocou neste ponto, Booth et al. (2001) analisaram a estrutura de capital de empresas em países em desenvolvimento e concluem que "as taxas de endividamento em países em desenvolvimento parecem ser afetadas da mesma maneira e pelos mesmos tipos de variáveis que são significantes em países desenvolvidos". Entretanto, ressaltam que "embora algumas das variáveis independentes tenham o sinal esperado, o seu impacto global é baixo e os sinais às vezes variam pelos países. Esta observação pode [...] também implicar diferenças institucionais significantes que afetam a importância das variáveis independentes" (BOOTH et el., 2001, p. 118). Esta última consideração aponta para a importância de se considerar fatores institucionais no estudo da estrutura de capital de empresas de diferentes países.

Por sua vez, questionando os determinantes comumente escolhidos para explicar a estrutura de capital de empresas, Faulkender e Petersen (2006) incorporam fatores relacionados não apenas ao lado da demanda por crédito (fatores específicos das empresas), mas também ao lado da oferta (fonte de capital). Segundo Faulkender e Petersen (2006, p. 46), "é importante incluir não apenas os determinantes da alavancagem preferida (o lado da demanda), mas também as variáveis que medem as limitações na habilidade de uma empresa em aumentar sua alavancagem (o lado da oferta)". Os autores incorporam a fonte de recursos (mercado de títulos de dívida ou privado) ao estudo da estrutura de capital e confirmam sua importância ao identificar diferentes impactos destas fontes na alavancagem das empresas.

Como contraponto, vale mencionar o trabalho de Terra (2007). O autor analisou se fatores macroeconômicos são importantes na determinação da estrutura de capital de empresas latino-americanas e concluiu que "os fatores que influenciam decisões de estrutura de capital são notavelmente semelhantes entre os países. Além disto, fatores específicos de empresas explicam muito mais do que os específicos de países" (TERRA, 2007, p. 202). Neste sentido, diferentemente de Booth et al. (2001) e Faulkender e Petersen (2006), o autor destaca a importância de se analisar características específicas de empresas e não fatores institucionais.

Antes de se colocar a abordagem pretendida neste trabalho, vale considerar as particularidades do caso brasileiro. No Brasil, é possível encontrar diferentes fontes e formas de captação baseadas em diversos indexadores de preços, assim como a presença de recursos de terceiros com diferentes amplitudes de custos financeiros devido à existência de taxas definidas livremente pelo mercado e taxas subsidiadas, dificultando a determinação da estrutura e do custo de capital das empresas brasileiras (ASSAF NETO, 2006).

A partir destas colocações, considerou-se importante incorporar à análise das estruturas de capital de empresas brasileiras fatores não exclusivamente centrados nas próprias características das empresas, mas também fatores institucionais. No Brasil, alguns destes fatores podem ser representados pelo acesso a fontes diferenciadas de recursos com taxas de juros exclusivas, como as linhas de financiamento provenientes de bancos de desenvolvimento e do Crédito Rural, e a linhas em moeda estrangeira.

O setor sucroalcooleiro brasileiro é um dos setores que pode se beneficiar da existência de diferentes alternativas de financiamento oferecidas por instituições financeiras privadas e públicas, com destaque para as linhas do Banco Nacional de Desenvolvimento Econômico e Social (BNDES) e do Crédito Rural, linhas consideradas incentivadas ou subsidiadas. Outro fator que merece destaque é a entrada recente de usinas brasileiras de açúcar e álcool para o mercado de capitais, possibilitando o acesso a outras fontes de captação de recursos, como a emissão de títulos de dívida ou ações.

Devido à relevância econômica, social e ambiental do setor sucroalcooleiro para o 
país, torna-se importante o desenvolvimento de pesquisas voltadas a conhecer as características do setor. Portanto, o objetivo deste estudo é conhecer qual a composição do endividamento de usinas brasileiras de açúcar e álcool, bem como a sua estratégia para enfrentar as altas taxas de juros do mercado interno, num cenário onde coexistem importantes fatores institucionais, como altas taxas de juros e linhas de financiamento tão diferenciadas. Mais especificamente, procura-se conhecer qual a participação das diferentes linhas de financiamento utilizadas (as quais serão agrupadas em quatro categorias: linhas diferenciadas em moeda nacional, linhas diferenciadas em moeda estrangeira, linhas de mercado em moeda nacional e linhas de mercado em moeda estrangeira), com o intuito de verificar a importância do acesso a estas linhas na determinação da estrutura de capital das usinas. Também procurase verificar se as usinas utilizaram, no período analisado, as estratégias de baixo endividamento e/ou alta liquidez para compensar as altas taxas de juros a que estavam sujeitas no mercado financeiro nacional, conforme discutido em Valle (2008).

Para tanto, são analisadas as usinas pertencentes ao banco de dados do Observatório do Setor Sucroalcooleiro, grupo de pesquisa da Faculdade de Economia, Administração e Contabilidade de Ribeirão Preto (FEA-RP), Universidade de São Paulo (USP). Ao todo, foram selecionadas 35 empresas que pertencem à região centro-sul e processam aproximadamente $33 \%$ de toda a cana-de-açúcar moída no país. A análise compreende um período de cinco anos-safra (2001/2002, 2002/2003, 2003/2004, 2004/2005 e 2005/2006).

$\mathrm{O}$ estudo é estruturado da seguinte forma: a seção 2 desenvolve o referencial teórico necessário para a fundamentação do trabalho. A seção 3 descreve a amostra, as variáveis e a metodologia utilizada. A seção 4 apresenta os resultados empíricos e a seção 5 apresenta as considerações finais. Espera-se que este trabalho contribua para a literatura brasileira sobre estrutura de capital, bem como para o estudo do setor sucroalcooleiro brasileiro.

\section{REFERENCIAL TEÓRICO}

Um dos estudos seminais existentes na literatura de estrutura de capital, The Cost of Capital, Corporation Finance and the Theory of Investment, de Modigliani e Miller (1958), trabalha estrutura de capital a partir do custo de capital total (retorno exigido por credores e acionistas) da empresa. Os autores mostram que considerando mercados perfeitos (inexistência de custos de transação ou falência e ausência de informação assimétrica) e a inexistência de impostos, o custo de capital total de uma empresa e, conseqüentemente, seu valor independe de sua estrutura de capital. Assim sendo, as decisões de financiamento são irrelevantes para a avaliação da empresa, sendo relevantes apenas suas decisões de investimentos, não existindo uma estrutura ótima de capital. Posteriormente, Modigliani e Miller (1963) afirmam que a utilização de dívida como fonte de financiamento é vantajosa devido ao benefício fiscal obtido pela dedução de despesas financeiras do cálculo do Imposto de Renda.

A partir destes trabalhos, longa discussão se estabeleceu, muitos trabalhos foram realizados e outras teorias foram elaboradas na tentativa de explicar o que determina a utilização de capital próprio ou de terceiros pelas empresas. Dentre estas, destacam-se a teoria de Trade-off , a Pecking Order e a teoria do Free Cash Flow.

De acordo com Myers (2001), a Teoria de Trade-off enfatiza impostos e prediz que empresas procuram níveis de dívida que permitam balancear benefícios fiscais e custos de dificuldades financeiras (financial distress), representados pelos custos de falência ou reorganização e custos de agência. Segundo esta teoria, as empresas têm um nível-alvo de dívida a ser ajustado gradualmente. Assim, quanto mais lucrativa a empresa, mais lucro tributável ela tem a proteger, logo, maior a utilização de dívida como fonte de financiamento devido ao benefício fiscal obtido por meio desta forma de captação, além da redução de problemas derivados do excesso de fluxo de caixa em poder de administradores. Outro 
aspecto presente nesta teoria é a postura conservadora em relação ao nível de endividamento. Uma empresa com foco na riqueza do acionista nunca evitará a utilização de dívida se a probabilidade de dificuldades financeiras for baixa.

A Teoria de Pecking Order, de Myers (1984) e Myers e Majluf (1984), não prediz um nível-alvo ou ótimo de capital, mas que as empresas seguem uma ordem hierárquica de preferências por tipos de financiamento, utilizando primeiramente recursos internos, em segundo lugar recursos captados por meio de dívida e em último lugar recursos captados por meio da emissão de ações. Esta ordem está baseada na informação transmitida ao mercado por cada tipo de título emitido, sendo preferíveis os títulos menos sensíveis à informação. Segundo a teoria, a empresa irá optar pelo uso de dívida, ao invés de emitir ações, quando seu fluxo de caixa interno não for suficiente para financiar seus dispêndios de capital. Assim, o montante de dívida irá refletir a necessidade acumulada da empresa por fundos externos.

Já a Teoria do Free Cash Flow considera custos de agência. Como Jensen e Meckling (1976) afirmaram, administradores agirão de acordo com seus próprios interesses econômicos e o alinhamento entre os objetivos de acionistas e administradores é necessariamente imperfeito. Assim, uma maneira de fazer com que administradores distribuam caixa ao invés de investi-lo abaixo do custo de capital ou desperdiçá-lo com ineficiências operacionais é a utilização de dívida, a qual funcionaria como instrumento disciplinador para administradores devido ao surgimento de obrigações financeiras a cumprir. Dessa forma, a dívida reduziria o free cash flow (caixa que excede o montante necessário para financiar todos os projetos com valor presente líquido positivo) em poder de administradores.

Cabe, neste momento, questionar se estas teorias seriam capazes de explicar a estrutura de capital das empresas brasileiras. Sem considerar importantes fatores ambientais e institucionais existentes em nossa economia, como altas taxas de juros e diversas fontes e linhas diferenciadas de financiamento, fatores que poderiam influenciar a escolha pela utilização de diferentes fontes de recursos, é possível estudar a estrutura de capital das empresas brasileiras?

O estudo de Rajan e Zingales (1995), um dos trabalhos relevantes da literatura de estrutura de capital, verifica se os fatores determinantes das estruturas de capital de empresas norte-americanas também são importantes para explicar as estruturas de capital de empresas de outros países, analisando empresas do chamado G-7 (Estados Unidos, Japão, Alemanha, França, Itália, Reino Unido e Canadá). Rajan e Zingales (1995, p. 1458) concluem que:

a alavancagem da firma é mais semelhante entre os países do G-7 do que o pensado anteriormente, e as diferenças que existem não são facilmente explicadas através de diferenças institucionais como pensado anteriormente ser importante. Os fatores identificados por estudos de cortes transversais nos Estados Unidos como relacionados a alavancagem parecem relacionados semelhantemente em outros países tão bem quanto.

Ressaltam ainda que é necessário um entendimento mais profundo dos efeitos das diferenças institucionais entre países, o que permitiria identificar quais os determinantes fundamentais da estrutura de capital das empresas.

Booth et al. (2001) argumentam que grande parte do nosso conhecimento sobre estrutura de capital é derivada de dados de economias desenvolvidas, as quais possuem muitas características institucionais similares. Então, se propõem a estudar os determinantes da estrutura de capital de empresas em países em desenvolvimento com diferentes estruturas institucionais. Para tanto, utilizam dados de 10 países em desenvolvimento (Índia, Paquistão, Tailândia, Malásia, Turquia, Zimbábue, México, Brasil, Jordânia e Coréia) e comparam os resultados com os de países desenvolvidos, do chamado G-7 (Estados Unidos, Japão, Alemanha, França, Itália, Reino Unido e Canadá). Buscam verificar se as decisões de 
alavancagem diferem muito entre países em desenvolvimento e países desenvolvidos; se os fatores que afetam a estrutura de capital entre países desenvolvidos e em desenvolvimento são similares; e se os modelos convencionais de estrutura de capital são desenvolvidos considerando a nacionalidade da empresa. Os dados de países em desenvolvimento foram extraídos do International Finance Corporation (IFC) e os dados de países desenvolvidos são de Rajan e Zingales (1995). O período de análise compreende 1980 a 1991.

Como resposta às duas primeiras perguntas os autores citam que os índices de endividamento de países em desenvolvimento são afetados da mesma maneira e pelas mesmas variáveis que são significantes em países desenvolvidos, porém existem diferenças sistemáticas na maneira como estes índices são afetados por fatores institucionais dos diferentes países, como a taxa de crescimento, o índice de inflação e o desenvolvimento do mercado de capitais. Como resposta à terceira pergunta, os autores afirmam que "conhecer o país de origem é normalmente tão importante quanto conhecer o tamanho das variáveis independentes para ambas as taxas de endividamento contábil de longo prazo e total. Apenas para a taxa de endividamento de mercado que isto não é verdadeiro" (BOOTH et al. 2001, p. 119).

Voltando para uma análise das características do mercado brasileiro, as quais podem gerar impactos na estrutura de capital das empresas, Brito et al. (2007, p. 11) apontam que uma das características deste mercado:

[...] é o fato de o custo de capital de terceiros não ser função apenas do risco do tomador, mas também da natureza da fonte de financiamento. Em razão disso, determinadas linhas de crédito de longo prazo direcionadas a investimentos específicos têm custo financeiro inferior a linhas de curto prazo, cujo risco de crédito para o credor normalmente é menor.

Neste sentido, cabe mencionar o trabalho de Faulkender e Petersen (2006), que analisam o lado da oferta da dívida ao incorporar neste estudo o acesso a fontes diferenciadas de financiamento e a influência deste acesso sobre a estrutura de capital das empresas analisadas. Os autores demonstram que o nível de endividamento pode não ser apenas uma função da demanda das empresas por dívida e afirmam "que nem todas as empresas podem estar aptas a escolher a fonte do capital da sua dívida. Se empresas que não têm acesso aos mercados de dívida pública são limitadas por credores na quantia de capital de dívida que elas podem tomar, nós deveríamos ver isto em seus baixos níveis de endividamento" (FAULKENDER; PETERSEN, 2006, p. 2).

Para tratar este aspecto, Faulkender e Petersen (2006) analisam o lado da oferta de crédito, considerando o nível de alavancagem uma função do acesso da empresa ao mercado de capitais. Os autores diferenciam empresas que têm acesso ao mercado de títulos de dívida (bonds) e empresas que têm acesso ao mercado de dívida privado (bancos) e verificam a influência do acesso a diferentes fontes de recursos nas suas estruturas de capital. As empresas analisadas foram extraídas do banco de dados da Compustat, e o período analisado compreende 1986 a 2000. Como resultados principais, destacam-se: empresas que têm acesso ao mercado de títulos de dívida (bonds) são muito mais alavancadas que empresas que não têm $(28,4 \%$ versus $17,9 \%)$; mesmo após controlar características específicas de empresas (tamanho, rentabilidade, tangibilidade etc.) apontadas por trabalhos teóricos e empíricos como determinantes da estrutura de capital, encontra-se que empresas com acesso ao mercado de títulos de dívida têm alavancagem mais alta.

Terra (2007) foi outro autor a destacar a necessidade de se incorporar outros fatores, além dos convencionais, para entender as decisões de estrutura de capital das empresas. A análise é realizada em empresas de 7 países latino-americanos (Argentina, Brasil, Chile, Colômbia, México, Peru e Venezuela). O objetivo foi verificar se fatores macroeconômicos 
(crescimento do PIB, taxa de inflação, taxa de juros e retorno das ações) são importantes na determinação da estrutura de capital destas empresas. Como variáveis específicas das empresas, foram utilizadas: tangibilidade, rentabilidade, tamanho, opções de crescimento, alíquota efetiva de impostos e risco do negócio.

Em seus resultados, Terra (2007) verifica que as variáveis específicas às empresas possuem maior poder de explicação de suas estruturas de capital, visto que dominam todas as outras. A inclusão das variáveis macroeconômicas pouco alterou o poder de explicação do modelo. Para o autor, os resultados não são suficientes para explicar as decisões de estrutura de capital das empresas, mas afirma que é preciso enfatizar as características das empresas e não as questões institucionais no estudo dos determinantes da estrutura de capital: "[...] os resultados indicam que os determinantes da estrutura de capital sugeridos pelas teorias tradicionais, embora pertinentes, não parecem capturar toda a história. Existem evidências para acreditar que outros fatores específicos de empresas, ainda desconhecidos, podem avançar a compreensão deste fenômeno" (TERRA, 2007, p. 202).

Juntando a argumentação de autores que apontaram a necessidade de se incorporar fatores institucionais nos estudos de estrutura de capital (Rajan e Zingales, 1995; Booth et al., 2001) com as particularidades da economia brasileira, defende-se que o estudo não se restrinja às próprias características das empresas. No Brasil, alguns destes fatores podem ser representados pelo acesso a fontes diferenciadas de recursos com taxas de juros exclusivas, como as linhas de financiamento provenientes do BNDES e do Crédito Rural, e linhas em moeda estrangeira.

Dois importantes recursos oriundos do BNDES muito utilizados pelo setor sucroalcooleiro são as linhas provenientes do FINAME (Financiamento para Aquisição de Máquinas e Equipamentos) e do FINEM (Financiamento a Empreendimentos). Já o Crédito Rural é um percentual obrigatório dos depósitos à vista que instituições financeiras devem destinar ao crédito agrícola, segundo as normas e procedimentos estabelecidos no Manual do Crédito Rural (MCR). O Crédito Rural pode ser concedido pelas instituições financeiras por meio da utilização de recursos obrigatórios, os quais oferecem taxas de juros diferenciadas, e por meio da utilização de recursos livres, os quais oferecem recursos às taxas praticadas no mercado. Finalmente, as linhas de financiamento em moeda estrangeira podem apresentar taxas de juros mais atrativas para estas empresas que as linhas em moeda nacional.

$\mathrm{Na}$ Tabela 1 é possível visualizar as taxas de juros brasileiras no período estudado.

Tabela 1 - Juros (em final de período)

\begin{tabular}{l|c|c|c|c|c}
\hline & DI & TJLP & CR & Libor & CC \\
\hline $\mathbf{2 0 0 2}$ & $24,83 \%$ & $10,00 \%$ & $8,75 \%$ & $1,45 \%$ & $21,00 \%$ \\
$\mathbf{2 0 0 3}$ & $16,27 \%$ & $11,00 \%$ & $8,75 \%$ & $1,46 \%$ & $2,68 \%$ \\
$\mathbf{2 0 0 4}$ & $17,76 \%$ & $9,75 \%$ & $8,75 \%$ & $3,10 \%$ & $2,93 \%$ \\
$\mathbf{2 0 0 5}$ & $17,99 \%$ & $9,75 \%$ & $8,75 \%$ & $4,84 \%$ & $4,39 \%$ \\
$\mathbf{2 0 0 6}$ & $13,17 \%$ & $6,85 \%$ & $8,75 \%$ & $5,33 \%$ & $5,43 \%$ \\
\hline
\end{tabular}

Legenda:

DI: Taxa média dos Depósitos Interfinanceiros (CETIP)

TJLP: Taxa de Juros de Longo Prazo (BNDES)

CR: taxa das operações de Crédito Rural

Libor: London Interbank Offered Rate (BBA)

CC: taxa do Cupom Cambial (BM\&F).

Fontes: Câmara de Liquidação e Custódia (CETIP) (www.cetip.com.br); Banco Nacional de Desenvolvimento Econômico e Social (BNDES) (www.bndes.gov.br); Banco Central do Brasil (www.bcb.gov.br); British Bankers Association (BBA) (www.bba.org.uk); e Bolsa de Mercadorias \& Futuros (BM\&F) (www.bmf.com.br).

A Tabela 1 confirma o diferencial de taxas das operações do BNDES e do Crédito 
Rural comparativamente a linhas de mercado. A TJLP (Taxa de Juros de Longo Prazo), taxa referencial para os financiamentos obtidos junto ao BNDES, e a CR (taxa das operações de Crédito Rural) representam taxas diferenciadas em relação às taxas de mercado, formadas a partir das taxas dos depósitos interfinanceiros (DI).

Já o diferencial das taxas das linhas em moeda estrangeira pode ser verificado analisando-se a Libor (London Interbank Offered Rate), que é a base para a maioria dos empréstimos internacionais. A Tabela 1 mostra que a Libor manteve-se muito menor que a taxa DI no período analisado. No entanto, estas taxas não podem ser comparadas diretamente devido, principalmente, as expectativas em relação à inflação e taxas cambiais. Uma das formas de minimizar este problema é a comparação da Libor com o Cupom Cambial, o qual é obtido a partir das taxas DI e das taxas cambiais dos mercados à vista e futuro de dólares. Ao comparar a Libor com o CC (Cupom Cambial) também é notável o diferencial entre as taxas em parte do período analisado.

Em seu estudo, Valle (2008) encontra que estas linhas tiveram grande participação no endividamento de empresas brasileiras no período analisado e que a inclusão destas linhas nos modelos de determinação do nível de endividamento contribuiu para o entendimento da estrutura de capital das empresas estudadas.

Neste trabalho não se pretende testar as teorias existentes, mas verificar se fatores institucionais, como o acesso a fontes de recursos diferenciadas (como BNDES e Crédito Rural e recursos em moeda estrangeira), influenciaram na escolha entre diferentes alternativas para a captação de recursos junto ao mercado financeiro e, conseqüentemente, na estrutura de capital de usinas brasileiras de açúcar e álcool, por meio de uma análise da composição do endividamento de uma amostra de 35 usinas pertencentes à região centro-sul do país.

\section{DADOS E METODOLOGIA}

\subsection{Amostra}

Propõe-se um estudo empírico-analítico em usinas brasileiras de açúcar e álcool. Segundo Martins (2002, p. 34), os estudos empírico-analíticos "são abordagens que apresentam em comum a utilização de técnicas de coleta, tratamento e análise de dados marcadamente quantitativas. Privilegiam estudos práticos. Suas propostas têm caráter técnico, restaurador e incrementalista".

Nesta pesquisa não é pretendido testar a relação causal existente entre variáveis para realizar inferências sobre a forma como as decisões de financiamento são tomadas pelas empresas, mas procurou-se analisar detalhadamente o que compõe o grupo "Empréstimos e Financiamentos" destas empresas para então chegar a algumas considerações sobre sua política de financiamento. Assim, optou-se por uma análise da composição do financiamento e da estrutura de capital das usinas de uma amostra de empresas do setor sucroalcooleiro por meio de estatísticas descritivas. A amostra utilizada no trabalho pertence ao banco de dados do Observatório do Setor Sucroalcooleiro, grupo de pesquisa da Faculdade de Economia, Administração e Contabilidade de Ribeirão Preto (FEA-RP), Universidade de São Paulo (USP), que tem por objetivo o desenvolvimento de pesquisas no setor.

Para a coleta de dados foi realizada análise documental das demonstrações contábeis das empresas pertencentes à amostra. Foram coletadas informações do Balanço Patrimonial e Notas Explicativas de cinco anos-safra (2001/2002, 2002/2003, 2003/2004, 2004/2005 e 2005/2006), informações estas relacionadas a caixas e bancos, aplicações financeiras de curto prazo, ativo total, passivo oneroso de curto prazo, passivo oneroso de longo prazo e empréstimos e financiamentos detalhados em notas explicativas.

Para a realização do estudo, foram analisadas todas as demonstrações contábeis de usinas (incluindo grupos) existentes no banco de dados (56 usinas no total), utilizando-se 
dados de apenas 35 usinas, as quais possuíam além das informações contidas no Balanço Patrimonial, o detalhamento dos empréstimos e financiamentos para três anos-safra ou mais. Algumas usinas não disponibilizavam informações em todos os anos, dessa forma, foi possível obter 20 usinas com cinco anos, 9 usinas com 4 anos e 6 usinas com três anos-safra analisados, totalizando 154 observações.

Para a obtenção de outras informações foram realizadas buscas na Rede Mundial de Computadores (Internet), utilizando-se os sítios da Imprensa Oficial de São Paulo, da Imprensa Oficial do Mato Grosso, além dos sítios das próprias empresas analisadas. As informações de moagem de cana-de-açúcar por usina, para a região centro-sul e Brasil, foram extraídas do sítio da União dos Produtores de Bioenergia (UDOP).

Todas as empresas da amostra pertencem à região centro-sul, onde o período de safra ocorre de abril a setembro e o ano-safra, de maio a abril. As empresas da amostra selecionada processam aproximadamente $38 \%$ de toda cana moída na região centro-sul e $33 \%$ de toda a cana moída no país. Os dados de moagem, em toneladas de cana-de-açúcar por ano-safra, podem ser visualizados na Figura 1.

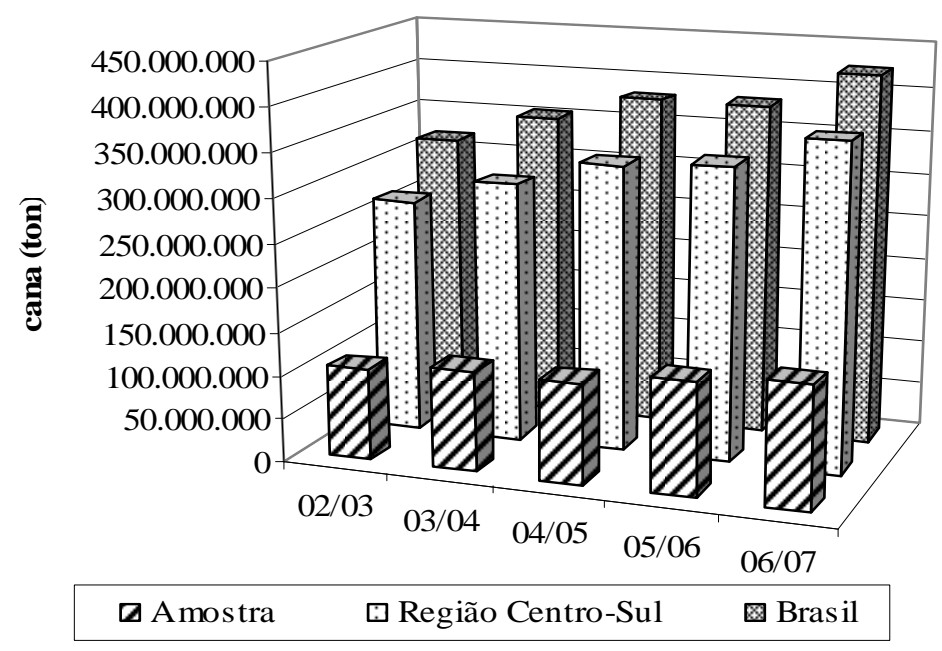

Figura 1 - Moagem de cana-de-açúcar Fonte: UDOP.

\subsection{Níveis de endividamento e liquidez}

Além da composição do endividamento, busca-se verificar se as usinas utilizaram no período as estratégias de baixo endividamento e/ou alta liquidez para compensar as altas taxas de juros do mercado nacional. Para tanto, foram calculados os seguintes indicadores de nível de endividamento: a) relação entre o Passivo Oneroso e o Ativo (PO/A); b) relação entre o Passivo Oneroso de Curto Prazo e o Ativo (POcp/A); e c) relação entre o Passivo Oneroso de Longo Prazo e o Ativo (POlp/A).

Os Passivos Onerosos são compostos por Empréstimos e Financiamentos de Curto Prazo, Debêntures de Curto Prazo, Empréstimos e Financiamentos de Longo Prazo e Debêntures de Longo Prazo, grupos extraídos das demonstrações contábeis das usinas.

A inclusão da variável liquidez se justifica pelo fato de o mercado financeiro ter oferecido ao longo do período analisado taxas que serviram para compensar, pelo menos parcialmente, as taxas de juros passivas, permitindo, por exemplo, ganhos de arbitragem com captações advindas de fontes alternativas. Assim sendo, o indicador de liquidez foi calculado da seguinte forma:

Liquidez $=$ Ativos Financeiros/Passivo Oneroso. 
Sendo que os ativos financeiros são compostos pelos grupos Caixas e Bancos e Aplicações Financeiras de Curto Prazo. Espera-se encontrar uma relação positiva entre o nível de endividamento e o indicador de liquidez. Dentre os indicadores de liquidez existentes, considerou-se este o mais adequado para analisar tal relação, visto que o mesmo é composto por ativos caixa e quase-caixa (bancos e aplicações financeiras) e passivos onerosos.

\subsection{Linhas de Financiamento}

Para a análise da composição do endividamento das usinas, as linhas de financiamento encontradas em notas explicativas foram classificadas em quatro categorias, sugeridas por Valle (2008), são elas: a) linhas diferenciadas em moeda nacional (1N); b) linhas diferenciadas em moeda estrangeira (1E); c) linhas de mercado em moeda nacional $(2 \mathrm{~N})$; e d) linhas de mercado em moeda estrangeira (2E).

De acordo com Valle (2008), a classificação entre Tipo 1 (linha diferenciada) e Tipo 2 (linha de mercado) é realizada a partir da instituição financiadora, da origem dos recursos e/ou do indexador da operação. Como exemplos de financiamentos Tipo 1 encontrados nas notas explicativas das usinas pertencentes à amostra, podem ser citados os que foram classificados a partir:

a) da instituição financiadora - BNDES, Banco de Desenvolvimento de Minas Gerais (BDMG), etc.;

b) da origem dos recursos - Fundo de Assistência ao Trabalhador (FAT), Fundo Constitucional de Financiamento do Centro-Oeste (FCO), Crédito Rural, etc.; e

c) do indexador - Taxa de Juros de Longo Prazo (TJLP), Taxa Referencial (TR), Taxa das operações de Crédito Rural, etc.

Já a classificação entre moeda nacional e estrangeira é realizada a partir:

a) da separação que as empresas fazem nas próprias Notas Explicativas entre os dois grupos (financiamentos em moeda nacional e estrangeira);

b) da informação da moeda do financiamento: Real, Dólar, etc.; e

c) do indexador: Libor, variações cambiais, etc.

Após a classificação de todos os financiamentos, de cada empresa em uma das quatro categorias, foi calculada a participação de cada categoria no total do financiamento, de forma que cada variável assumisse valores de 0 a 1 e que a soma das quatro categorias em cada empresa em cada ano totalizasse 1.

O Quadro 1 apresenta as linhas de financiamento encontradas na amostra, bem como sua classificação de acordo com os critérios acima mencionados. Muitas usinas apresentavam em seus passivos Obrigações com a Copersucar. Estes financiamentos também estavam detalhados em notas explicativas e, dessa forma, foi possível classificá-los dentro das quatro categorias de acordo com as características dos recursos obtidos pela cooperativa junto ao mercado financeiro e repassados para as usinas.

Como citado anteriormente, o Crédito Rural pode ser concedido pelas instituições financeiras a taxas de juros diferenciadas e a taxas livres de mercado, pois o MCR 6.2.2 estabelece que "as instituições financeiras são obrigadas a manter em aplicações de crédito rural $25 \%$ (vinte e cinco por cento) do saldo médio diário das rubricas contábeis de recursos à vista sujeitos ao recolhimento compulsório". Mas o MCR 6.3.1 diz que "admite-se a concessão de crédito rural com recursos livres das instituições financeiras, às taxas de operações bancárias comuns". Assim sendo, a análise considerou apenas as usinas em que foi possível visualizar em suas demonstrações contábeis a parte destes recursos considerada livre ou obrigatória, para a sua correta classificação entre linha do tipo $2 \mathrm{~N}$ ou $1 \mathrm{~N}$, respectivamente.

O Programa Especial de Saneamento de Ativos (PESA), ou Resolução n. 2.471/98 do Conselho Monetário Nacional, permitiu às usinas a renegociação a taxas subsidiadas e o 
alongamento de suas dívidas originárias de crédito rural. Como será demonstrado posteriormente, esta operação teve grande participação no endividamento das usinas da amostra.

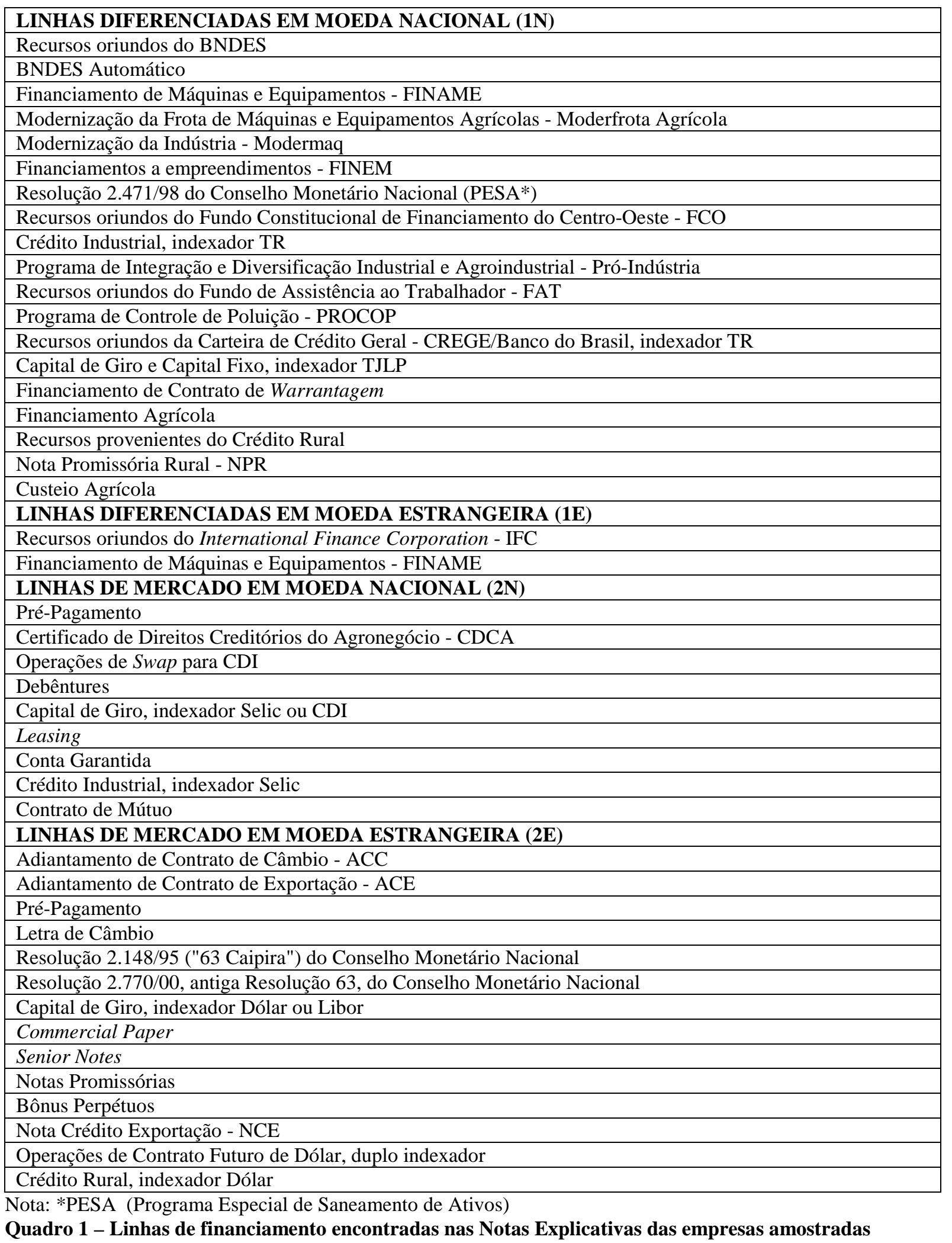




\section{RESULTADOS}

Com o intuito de alcançar um dos objetivos deste trabalho, analisar a composição do endividamento de usinas de açúcar e álcool da região centro-sul do país, primeiramente serão apresentados os resultados relativos à participação das diferentes linhas de financiamento no endividamento das usinas pertencentes à amostra. Em seguida, para o alcance de mais um objeto do trabalho, serão apresentados os resultados referentes ao nível de endividamento e liquidez, buscando analisar se as usinas utilizaram no período as estratégias de baixo endividamento e/ou alta liquidez para compensar as altas taxas de juros do mercado nacional.

As Tabelas 2 e 3 apresentam estatísticas descritivas para as variáveis utilizadas no estudo. Alguns pontos que merecem destaque são: o crescimento de linhas do tipo $1 \mathrm{~N}$ e $2 \mathrm{E}$ no período, o crescimento de linhas do tipo $2 \mathrm{E}$ no último ano (2006), a significativa participação de empréstimos e financiamentos de longo prazo no passivo oneroso e o grande crescimento do Ativo e de Ativos Financeiros.

Tabela 2 - Estatísticas descritivas (em R\$)

\begin{tabular}{|c|c|c|c|c|c|c|}
\hline Ano & Estatística & POcp & POlp & POtotal & Ativo & At. Fin. \\
\hline \multirow[t]{5}{*}{2002} & Soma & 703.646 .608 & 857.881 .791 & 1.561 .528 .399 & 5.701 .347 .740 & 547.813 .897 \\
\hline & Média & 23.454 .887 & 28.596 .060 & 52.050 .947 & 190.044 .925 & 18.260 .463 \\
\hline & Mínimo & 0 & 167.316 & 280.722 & 30.643 .306 & 286.000 \\
\hline & Máximo & 152.425 .000 & 134.523 .000 & 286.948 .000 & 814.128 .000 & 92.026 .000 \\
\hline & Desvio padrão & 33.885 .240 & 34.761 .345 & 65.717 .503 & 176.089 .999 & 23.750 .184 \\
\hline \multirow[t]{5}{*}{2003} & Soma & 1.042 .338 .340 & 1.365 .281 .631 & 2.407 .619 .970 & 8.361 .839 .694 & 758.093 .878 \\
\hline & Média & 34.744 .611 & 45.509 .388 & 80.253 .999 & 278.727 .990 & 25.269 .796 \\
\hline & Mínimo & 0 & 47.818 & 47.818 & 9.412 .963 & 837 \\
\hline & Máximo & 260.567 .000 & 419.124 .000 & 679.691 .000 & 2.149 .800 .000 & 132.954 .000 \\
\hline & Desvio padrão & 54.806 .809 & 80.470 .005 & 131.458 .050 & 404.762 .360 & 34.497 .662 \\
\hline \multirow[t]{5}{*}{2004} & Soma & 1.373 .217 .250 & 1.705 .129 .430 & 3.078 .346 .680 & 10.398 .765 .964 & 785.776 .676 \\
\hline & Média & 41.612 .644 & 51.670 .589 & 93.283 .233 & 315.114 .120 & 23.811 .414 \\
\hline & Mínimo & 0 & 0 & 42.192 & 19.167 .651 & 5.000 \\
\hline & Máximo & 367.494 .000 & 375.436 .000 & 742.930 .000 & 2.495 .200 .000 & 159.684 .000 \\
\hline & Desvio padrão & 72.462 .191 & 78.401 .782 & 147.762 .526 & 452.184 .726 & 37.847 .637 \\
\hline \multirow[t]{5}{*}{2005} & Soma & 1.022 .616 .921 & 2.443 .388 .242 & 3.466 .005 .163 & 12.595 .244 .181 & 790.972 .335 \\
\hline & Média & 30.076 .968 & 71.864 .360 & 101.941 .328 & 370.448 .358 & 23.263 .892 \\
\hline & Mínimo & 0 & 300.000 & 3.970 .000 & 35.593 .388 & 6.000 \\
\hline & Máximo & 139.544 .000 & 846.538 .000 & 899.229 .000 & 2.722 .400 .000 & 174.632 .000 \\
\hline & Desvio padrão & 31.970 .832 & 149.142 .563 & 162.344 .348 & 514.011 .967 & 37.292 .345 \\
\hline \multirow[t]{5}{*}{2006} & Soma & 1.122 .748 .194 & 3.914 .474 .600 & 5.037 .222 .793 & 15.743 .481 .004 & 1.572 .221 .326 \\
\hline & Média & 41.583 .266 & 144.980 .541 & 186.563 .807 & 583.091 .889 & 58.230 .419 \\
\hline & Mínimo & 0 & 2.548 .344 & 2.548 .344 & 62.452 .023 & 157.644 \\
\hline & Máximo & 132.375 .000 & 2.070 .500 .000 & 2.195 .069 .000 & 5.659 .400 .000 & 831.500 .000 \\
\hline & Desvio padrão & 38.145 .870 & 392.365 .177 & 414.586 .188 & 1.077 .629 .951 & 159.132 .095 \\
\hline
\end{tabular}

\section{Legenda:}

POcp: Passivo Oneroso de Curto Prazo

POlp: Passivo Oneroso de Longo Prazo

POtotal: Passivo Oneroso Total

At. Fin.: Ativos Financeiros 
Tabela 2 - Estatísticas descritivas (em R\$)

\begin{tabular}{|c|c|c|c|c|c|}
\hline Ano & Estatística & $1 \mathbf{N}$ & $1 E$ & $2 \mathbf{N}$ & $2 \mathbf{E}$ \\
\hline \multirow[t]{5}{*}{2002} & Soma & 537.131 .426 & 337.000 & 474.357 .248 & 549.702 .725 \\
\hline & Média & 17.904 .381 & 11.233 & 15.811 .908 & 18.323 .424 \\
\hline & Mínimo & 0 & 0 & 0 & 0 \\
\hline & Máximo & 76.459 .000 & 337.000 & 136.494 .000 & 150.454 .000 \\
\hline & Desvio padrão & 21.181 .765 & 61.528 & 30.471 .194 & 34.625 .713 \\
\hline \multirow[t]{5}{*}{2003} & Soma & 984.767 .010 & 407.000 & 538.695 .862 & 883.750 .098 \\
\hline & Média & 32.825 .567 & 13.567 & 17.956 .529 & 29.458 .337 \\
\hline & Mínimo & 0 & 0 & 0 & 0 \\
\hline & Máximo & 241.826 .000 & 215.000 & 142.869 .000 & 330.166 .000 \\
\hline & Desvio padrão & 49.083 .446 & 51.718 & 35.457 .142 & 66.711 .912 \\
\hline \multirow[t]{5}{*}{2004} & Soma & 1.133 .874 .764 & 304.000 & 736.857 .864 & 1.207 .310 .052 \\
\hline & Média & 34.359 .841 & 9.212 & 22.329 .026 & 36.585 .153 \\
\hline & Mínimo & 0 & 0 & 0 & 0 \\
\hline & Máximo & 270.466 .000 & 161.000 & 156.610 .000 & 361.704 .000 \\
\hline & Desvio padrão & 52.692 .777 & 36.899 & 39.135 .088 & 79.552 .317 \\
\hline \multirow[t]{5}{*}{2005} & Soma & 1.441 .105 .386 & 0 & 1.052.979.955 & 971.919 .823 \\
\hline & Média & 42.385 .453 & 0 & 30.969 .999 & 28.585 .877 \\
\hline & Mínimo & 0 & 0 & 0 & 0 \\
\hline & Máximo & 276.928 .000 & 0 & 557.768 .000 & 229.381 .000 \\
\hline & Desvio padrão & 56.447 .991 & 0 & 96.755 .893 & 46.235 .452 \\
\hline \multirow[t]{5}{*}{2006} & Soma & 1.867 .553 .480 & 139.723 .000 & 822.037 .818 & 2.207 .908 .495 \\
\hline & Média & 69.168 .647 & 5.174 .926 & 30.445 .845 & 81.774 .389 \\
\hline & Mínimo & 0 & 0 & 0 & 0 \\
\hline & Máximo & 501.361 .000 & 139.723 .000 & 524.870 .000 & 1.029 .115 .000 \\
\hline & Desvio padrão & 105.755 .444 & 26.889 .704 & 100.376 .599 & 196.416 .677 \\
\hline
\end{tabular}

\section{Legenda:}

$1 \mathrm{~N}$ : linhas diferenciadas em moeda nacional

1E: linhas diferenciadas em moeda estrangeira

$2 \mathrm{~N}$ : linhas de mercado em moeda nacional

2E: linhas de mercado em moeda estrangeira.

O crescimento de linhas diferenciadas em moeda nacional (tipo $1 \mathrm{~N}$ ) decorre da grande participação de financiamentos derivados do BNDES, linhas de FINAME e FINEM, e também do PESA. Como pode ser observado na tabela abaixo, estas linhas representaram, em média, $84 \%$ da somatória dos financiamentos do tipo $1 \mathrm{~N}$ no período. Algumas usinas não apresentavam em suas Notas Explicativas o detalhamento dos tipos de financiamentos obtidos junto ao BNDES, logo, na somatória de financiamentos classificados apenas como BNDES pelas usinas também pode haver FINAME e FINEM, não sendo possível afirmar qual a participação efetiva destas linhas. Já o PESA, que teve grande participação no endividamento das usinas brasileiras nos anos de 2002 e 2003, continua crescente de 2003 a 2006 . No entanto, os dados apontam que esta situação é causada por uma das usinas da amostra, o Grupo Cosan, o qual apresentou participação do PESA em Notas Explicativas nos valores de $\mathrm{R} \$$ 206.201.000, $\mathrm{R} \$ 214.331 .000, \mathrm{R} \$ 236.548 .000$ e $\mathrm{R} \$ 479.740 .000$ para os anos de 2003, 2004, 2005 e 2006, respectivamente. Caso esta usina não estivesse presente na análise, a participação do PESA se manteria praticamente constante de 2003 para 2004 e 2005, e em 2006 seria a menor do período. 
Tabela 3 - Participação de linhas do BNDES, FINAME/FINEM e PESA no total de linhas do tipo 1N

\begin{tabular}{|c|c|c|c|c|c|c|}
\hline $\begin{array}{c}\text { Linha de } \\
\text { Financiamento }\end{array}$ & $\begin{array}{c}2002 \\
\text { R\$ }\end{array}$ & $\%$ & $\begin{array}{c}2003 \\
\text { R\$ }\end{array}$ & & $\begin{array}{c}2004 \\
\text { R\$ }\end{array}$ & $\%$ \\
\hline BNDES & 55.275 .000 & $10,29 \%$ & 11.343 .000 & $1,15 \%$ & 46.540 .000 & $4,10 \%$ \\
\hline FINAME/FINEM & 247.307 .858 & $46,04 \%$ & 338.463 .565 & $34,37 \%$ & 445.362 .807 & $39,28 \%$ \\
\hline PESA & 145.321 .000 & $27,06 \%$ & 452.536 .063 & $45,95 \%$ & 460.320 .565 & $40,60 \%$ \\
\hline Total & 447.903.858 & $83,39 \%$ & 802.342.628 & $81,48 \%$ & 952.223.373 & $\mathbf{8 3 , 9 8 \%}$ \\
\hline Total 1N & 537.131 .426 & & 984.767.010 & & 1.133.874.764 & \\
\hline $\begin{array}{c}\text { Linha de } \\
\text { Financiamento }\end{array}$ & $\begin{array}{l}2005 \\
\text { R\$ } \\
\end{array}$ & $\%$ & $\begin{array}{c}2006 \\
\text { R\$ } \\
\end{array}$ & $\%$ & & \\
\hline BNDES & 71.854 .000 & $4,99 \%$ & 154.639 .000 & $8,28 \%$ & & \\
\hline FINAME/FINEM & 666.151 .164 & $46,23 \%$ & 807.665 .451 & $43,25 \%$ & & \\
\hline PESA & 500.176 .450 & $34,71 \%$ & 620.161 .000 & $33,21 \%$ & & \\
\hline Total & 1.238.181.613 & $85,92 \%$ & 1.582.465.451 & $84,73 \%$ & & \\
\hline Total 1N & 1.441.105.386 & & 1.867.553.480 & & & \\
\hline \multicolumn{7}{|c|}{$\begin{array}{l}\text { Legenda: } \\
\text { BNDES: linhas derivadas do BNDES sem especificação nas Notas Explicativas das usinas } \\
\text { 1N: linhas diferenciadas em moeda nacional. }\end{array}$} \\
\hline
\end{tabular}

Em relação aos financiamentos do tipo 2E (linhas de mercado em moeda estrangeira), verifica-se que a maior parte de sua composição é referente a operações de Pré-pagamento e Adiantamento de Contrato de Câmbio (ACC), as quais representaram, em média, $40 \%$ das linhas do tipo 2E no período. Já o crescimento de linhas do tipo $2 \mathrm{E}$ no último ano se deve a realização de uma operação de Bônus Perpétuos, no valor de R $\$ 960.577 .000$, por uma das usinas da amostra, o Grupo COSAN.

Estas análises permitem inferir que a significativa participação de linhas de longo prazo no passivo oneroso das empresas analisadas é oriunda, principalmente, de recursos do BNDES, do Programa Especial de Saneamento de Ativos - PESA e de operações de Prépagamento. A disponibilidade destes recursos fez com que a utilização de financiamentos de longo prazo, de mais difícil acesso, fosse maior que a de financiamentos de curto prazo no período analisado.

Já o significativo aumento do Ativo pode apontar para o grande crescimento do setor no período, o qual pode ter sido incentivado também pela disponibilização de diversas linhas de financiamento do BNDES e de linhas em moeda estrangeira. Finalmente, o aumento expressivo de Ativos Financeiros no período ocorre pela grande participação de Aplicações Financeiras de Curto Prazo, como demonstrado na Tabela 4.

Tabela 4 - Composição dos ativos financeiros (em R\$)

\begin{tabular}{l|r|r|r|r|r}
\hline & $\mathbf{2 0 0 2}$ & $\mathbf{2 0 0 3}$ & $\mathbf{2 0 0 4}$ & $\mathbf{2 0 0 5}$ & $\mathbf{2 0 0 6}$ \\
\hline Caixa e Bancos & 212.295 .820 & 309.377 .643 & 302.109 .053 & 298.800 .097 & 262.556 .181 \\
Aplic. Finac. CP & 335.518 .078 & 448.716 .235 & 483.667 .623 & 492.172 .238 & 1.309 .665 .145 \\
\hline Ativos Financeiros & 547.813 .897 & 758.093 .878 & 785.776 .676 & 790.972 .335 & 1.572 .221 .326 \\
\hline
\end{tabular}

A Tabela 5 apresenta estatísticas descritivas para os indicadores de nível de endividamento, para a participação das linhas de financiamento no endividamento total (Passivo Oneroso) e para o indicador de nível de liquidez. 
Tabela 5 - Estatísticas descritivas dos indicadores e linhas

\begin{tabular}{l|c|c|c|c|c}
\hline \multicolumn{1}{c|}{ Variáveis } & $\begin{array}{c}\text { Número de } \\
\text { observações }\end{array}$ & Média & Desvio padrão & Mínimo & Máximo \\
\hline PO/A & 154 & 0,317 & 0,475 & 0,001 & 5,459 \\
POcp/A & 154 & 0,108 & 0,081 & 0,000 & 0,382 \\
POlp/A & 154 & 0,210 & 0,480 & 0,000 & 5,459 \\
\hline & & & & & \\
\hline Tipo 1N & 154 & 0,505 & 0,338 & 0,000 & 1,000 \\
Tipo 1E & 154 & 0,001 & 0,005 & 0,000 & 0,064 \\
Tipo 2N & 154 & 0,267 & 0,311 & 0,000 & 1,000 \\
Tipo 2E & 154 & 0,228 & 0,253 & 0,000 & 0,886 \\
& & & & & \\
\hline Liquidez & 154 & 1,930 & 6,897 & 0,000 & 58,023 \\
\hline
\end{tabular}

Legenda:

PO/A: relação entre o Passivo Oneroso e o Ativo

POcp/A: relação entre o Passivo Oneroso de Curto Prazo e o Ativo

POlp/A: relação entre o Passivo Oneroso de Longo Prazo e o Ativo

Tipo 1N: linhas diferenciadas em moeda nacional

Tipo 1E: linhas diferenciadas em moeda estrangeira

Tipo 2N: linhas de mercado em moeda nacional

Tipo 2E: linhas de mercado em moeda estrangeira.

Em uma análise preliminar, nota-se que as usinas, em média, utilizaram mais financiamentos de longo prazo, o que só ocorre em decorrência da disponibilidade de diversas linhas de longo prazo do BNDES, do PESA e de operações de Pré-pagamento, como demonstrado anteriormente, e apresentaram um nível de endividamento total de aproximadamente $31 \%$. Com relação à composição do seu passivo oneroso, nota-se que as usinas, em média, utilizaram em primeiro lugar linhas diferenciadas do Tipo 1N (50\%). Em segundo lugar fica a participação de linhas de mercado em moeda nacional (2N) com $27 \%$. A participação de linhas de mercado em moeda estrangeira (Tipo 2E) também é bastante representativa, sendo de $23 \%$.

\subsection{Análise da composição do endividamento}

A Tabela 6 apresenta ano a ano, a participação média de cada tipo de linha de financiamento no passivo oneroso total das 35 usinas analisadas. Diferentemente do Quadro 1 , em que foram somados os reais $(\mathrm{R} \$)$ de financiamentos de todas as usinas, para a construção da Tabela 6 , inicialmente foi calculado o percentual de cada tipo de financiamento no passivo oneroso de cada usina para, num segundo momento, calcular a média dos percentuais de todas as usinas.

Tabela 6 - Participação média das linhas de financiamento no endividamento

\begin{tabular}{l|r|r|r|r|r}
\hline Financiamentos & \multicolumn{1}{c|}{$\mathbf{2 0 0 2}$} & $\mathbf{2 0 0 3}$ & $\mathbf{2 0 0 4}$ & \multicolumn{1}{c}{$\mathbf{2 0 0 5}$} & $\mathbf{2 0 0 6}$ \\
\hline Tipo 1N & $51,04 \%$ & $57,46 \%$ & $48,01 \%$ & $48,57 \%$ & $47,64 \%$ \\
Tipo 1E & $0,03 \%$ & $0,06 \%$ & $0,02 \%$ & $0,00 \%$ & $0,24 \%$ \\
Tipo 2N & $28,69 \%$ & $25,26 \%$ & $30,39 \%$ & $29,44 \%$ & $17,99 \%$ \\
Tipo 2E & $20,24 \%$ & $17,22 \%$ & $21,58 \%$ & $21,99 \%$ & $34,14 \%$ \\
\hline Tipo 1 & $51,07 \%$ & $57,51 \%$ & $48,03 \%$ & $48,57 \%$ & $47,87 \%$ \\
Tipo 2 & $48,93 \%$ & $42,49 \%$ & $51,97 \%$ & $51,43 \%$ & $52,13 \%$ \\
\hline Tipo N & $79,73 \%$ & $82,72 \%$ & $78,40 \%$ & $78,01 \%$ & $65,62 \%$ \\
Tipo E & $20,27 \%$ & $17,28 \%$ & $21,60 \%$ & $21,99 \%$ & $34,38 \%$ \\
\hline Total & $100,00 \%$ & $100,00 \%$ & $100,00 \%$ & $100,00 \%$ & $100,00 \%$ \\
\hline
\end{tabular}




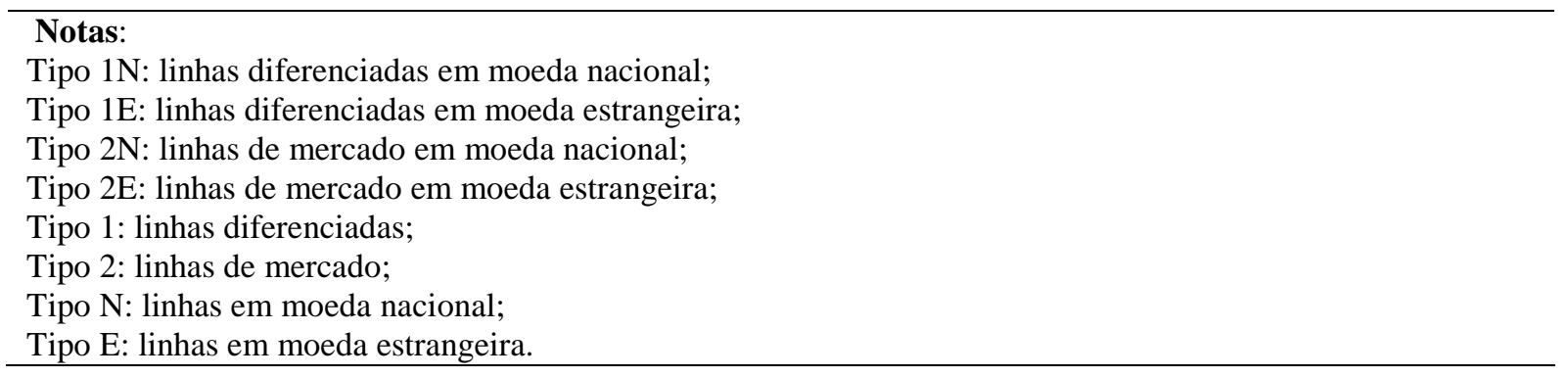

Na Tabela 6 é possível analisar a representatividade média de cada linha no endividamento total das usinas. Nota-se que as linhas diferenciadas em moeda nacional (tipo $1 \mathrm{~N})$ prevaleceram em todos os anos de análise, representando, em média, 50\% do passivo oneroso, o que confirma a influência do acesso a este tipo de recurso nas decisões de financiamento das usinas da amostra. A utilização de recursos em moeda estrangeira também é bastante significativa, representando uma alternativa à captação de recursos em linhas de mercado em moeda nacional.

Já a Tabela 7, apresenta ano a ano, em termos absolutos, a participação de cada tipo de linha de financiamento na somatória do passivo oneroso das usinas analisadas.

Tabela 7 - Participação das linhas de financiamento no endividamento (em R\$)

\begin{tabular}{|c|c|c|c|c|c|c|}
\hline \multirow[t]{2}{*}{ Financiamentos } & 2002 & & 2003 & & 2004 & \\
\hline & $\mathbf{R} \$$ & $\%$ & $\mathbf{R} \$$ & $\%$ & $\mathbf{R} \$$ & $\%$ \\
\hline Tipo 1N & 537.131 .426 & $34,40 \%$ & 984.767 .010 & $40,90 \%$ & 1.133 .874 .764 & $36,83 \%$ \\
\hline Tipo 1E & 337.000 & $0,02 \%$ & 407.000 & $0,02 \%$ & 304.000 & $0,01 \%$ \\
\hline Tipo $2 \mathbf{N}$ & 474.357 .248 & $30,38 \%$ & 538.695 .862 & $22,37 \%$ & 736.857 .864 & $23,94 \%$ \\
\hline Tipo 2E & 549.702 .725 & $35,20 \%$ & 883.750 .098 & $36,71 \%$ & 1.207 .310 .052 & $39,22 \%$ \\
\hline Tipo 1 & 537.468 .426 & $34,42 \%$ & 985.174 .010 & $40,92 \%$ & 1.134 .178 .764 & $36,84 \%$ \\
\hline Tipo 2 & 1.024 .059 .973 & $65,58 \%$ & 1.422 .445 .960 & $59,08 \%$ & 1.944.167.916 & $63,16 \%$ \\
\hline Tipo N & 1.011 .488 .674 & $64,78 \%$ & 1.523 .462 .872 & $63,28 \%$ & 1.870 .732 .628 & $60,77 \%$ \\
\hline Tipo E & 550.039 .725 & $35,22 \%$ & 884.157.098 & $36,72 \%$ & 1.207.614.052 & $39,23 \%$ \\
\hline Total & 1.561 .528 .399 & $100,00 \%$ & 2.407 .619 .970 & $100,00 \%$ & 3.078 .346 .680 & $100,00 \%$ \\
\hline
\end{tabular}

\begin{tabular}{l|r|c|c|c}
\hline \multirow{2}{*}{ Financiamentos } & $\mathbf{2 0 0 5}$ & & $\mathbf{2 0 0 6}$ & \\
\cline { 2 - 5 } & $\mathbf{R} \$$ & $\mathbf{\%}$ & $\mathbf{R} \mathbf{\%}$ & $\mathbf{\%}$ \\
\hline Tipo 1N & 1.441 .105 .386 & $41,58 \%$ & 1.867 .553 .480 & $37,08 \%$ \\
Tipo 1E & 0 & $0,00 \%$ & 139.723 .000 & $2,77 \%$ \\
Tipo 2N & 1.052 .979 .955 & $30,38 \%$ & 822.037 .818 & $16,32 \%$ \\
Tipo 2E & 971.919 .823 & $28,04 \%$ & 2.207 .908 .495 & $43,83 \%$ \\
\hline Tipo 1 & 1.441 .105 .386 & $41,58 \%$ & 2.007 .276 .480 & $39,85 \%$ \\
Tipo 2 & 2.024 .899 .778 & $58,42 \%$ & 3.029 .946 .313 & $60,15 \%$ \\
\hline Tipo N & 2.494 .085 .340 & $71,96 \%$ & 2.689 .591 .298 & $53,39 \%$ \\
Tipo E & 971.919 .823 & $28,04 \%$ & 2.347 .631 .495 & $46,61 \%$ \\
\hline Total & 3.466 .005 .163 & $100,00 \%$ & 5.037 .222 .793 & $100,00 \%$ \\
\hline
\end{tabular}

\footnotetext{
Legendas:

Tipo 1N: linhas diferenciadas em moeda nacional

Tipo 1E: linhas diferenciadas em moeda estrangeira

Tipo 2N: linhas de mercado em moeda nacional

Tipo 2E: linhas de mercado em moeda estrangeira

Tipo 1: linhas diferenciadas

Tipo 2: linhas de mercado

Tipo N: linhas em moeda nacional

Tipo E: linhas em moeda estrangeira.
} 
Ao analisar a representatividade das linhas em termos absolutos, nota-se que, no período analisado, as usinas utilizaram em primeiro lugar recursos provenientes de linhas diferenciadas em moeda nacional $(1 \mathrm{~N})$ e em segundo lugar recursos provenientes de linhas de mercado em moeda estrangeira (2E). Estas linhas oferecem taxas de juros mais atrativas e constituem uma alternativa para as empresas fugirem das altas taxas de juros das linhas de mercado em moeda nacional $(2 \mathrm{~N})$, as quais ficaram em terceiro lugar, confirmando a utilização desta alternativa pelas usinas. A captação de recursos por meio de linhas diferenciadas em moeda estrangeira (1E), como são os recursos oriundos do International Finance Corporation (IFC), é pouco representativa.

$\mathrm{Na}$ Figura 2 é possível visualizar a evolução da participação de cada tipo de financiamento no endividamento total ao longo do período.

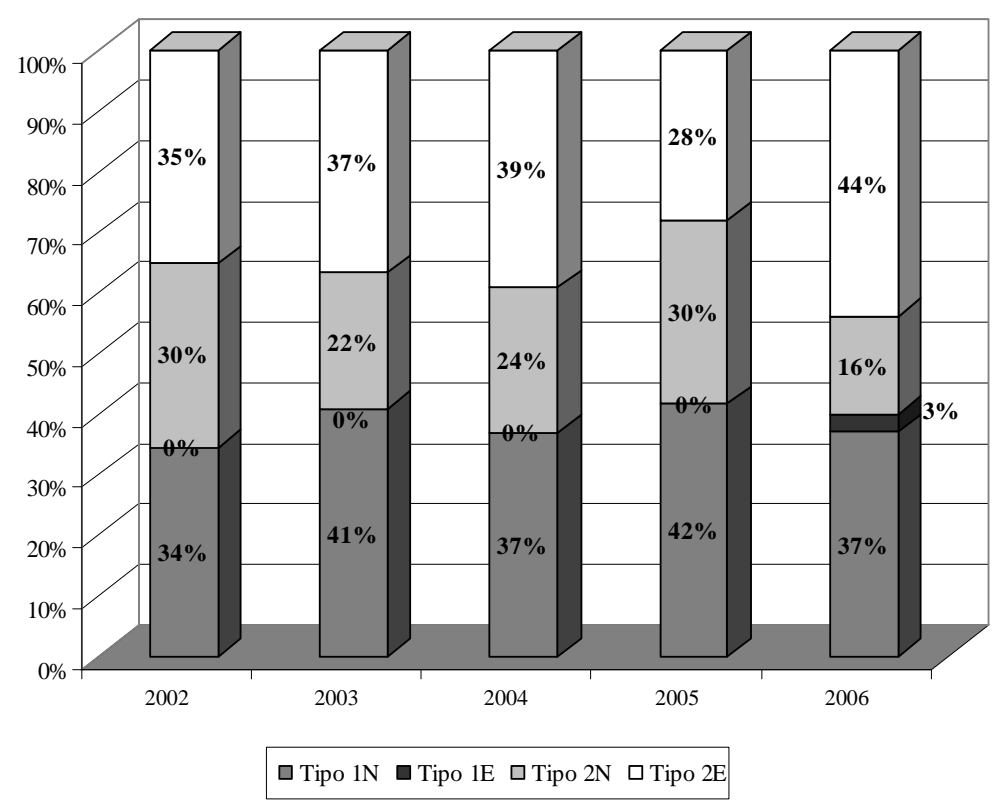

Figura 2 - Participação das linhas de financiamento no endividamento

Verifica-se na Figura 2 que nos anos de 2002, 2004 e 2006 os recursos captados em moeda estrangeira lideram os financiamentos realizados pelas empresas, ao passo que também ocorre uma redução significativa em financiamentos por meio de linhas de mercado em moeda nacional no último ano. Os recursos em moeda estrangeira muitas vezes apresentaram como base de custo a taxa Libor (London Interbank Offered Rate), menor que as taxas exigidas pelo mercado nacional, o que, talvez, explique a maior participação de linhas do tipo $2 \mathrm{E}$ no período. Já no ano de 2006, o aumento expressivo na participação de linhas do tipo $2 \mathrm{E}$ é explicado pela existência de R $\$ 960.577 .000$ em Bônus Perpétuos nos financiamentos de uma das usinas da amostra, como mencionado. Dessa forma, considera-se que até 2002 a alta participação de linhas em moeda estrangeira pode ser explicada pelo diferencial entre as taxas Libor e o Cupom Cambial, o que permanece até 2004. Já no final do período analisado, 2005 e 2006, com a disponibilidade de linhas de pré-pagamento, as quais permitem às empresas alongarem o seu financiamento, a participação de linhas em moeda estrangeira continua significativa mesmo com a redução da diferença entre as taxas Libor e o Cupom Cambial.

A participação de linhas diferenciadas em moeda nacional (1N) também é significativa em todos os anos, prevalecendo sobre as linhas de mercado em moeda nacional $(2 \mathrm{~N})$, em decorrência da disponibilidade de diversas linhas do BNDES e também pela grande participação do PESA. 
É possível inferir com base na análise da composição do endividamento que, para fugir das taxas de juros do mercado nacional, as usinas utilizaram recursos derivados de linhas diferenciadas em moeda nacional e de linhas em moeda estrangeira. Isso ratifica a importância da inclusão de fatores institucionais na análise da estrutura de capital das empresas, visto que estes fatores podem influenciar as decisões de financiamento por elas tomadas.

\subsection{Análise do nível de endividamento}

Também procurou-se verificar se as usinas analisadas utilizaram no período a estratégia de baixa alavancagem devido ao ambiente de altas taxas de juros no qual estavam inseridas. Na Figura 3 possível acompanhar a evolução da somatória dos grupos Ativo Total, Passivo Oneroso de Curto Prazo, Passivo Oneroso de Longo Prazo e Passivo Oneroso Total, os quais formam os índices de endividamento calculados.
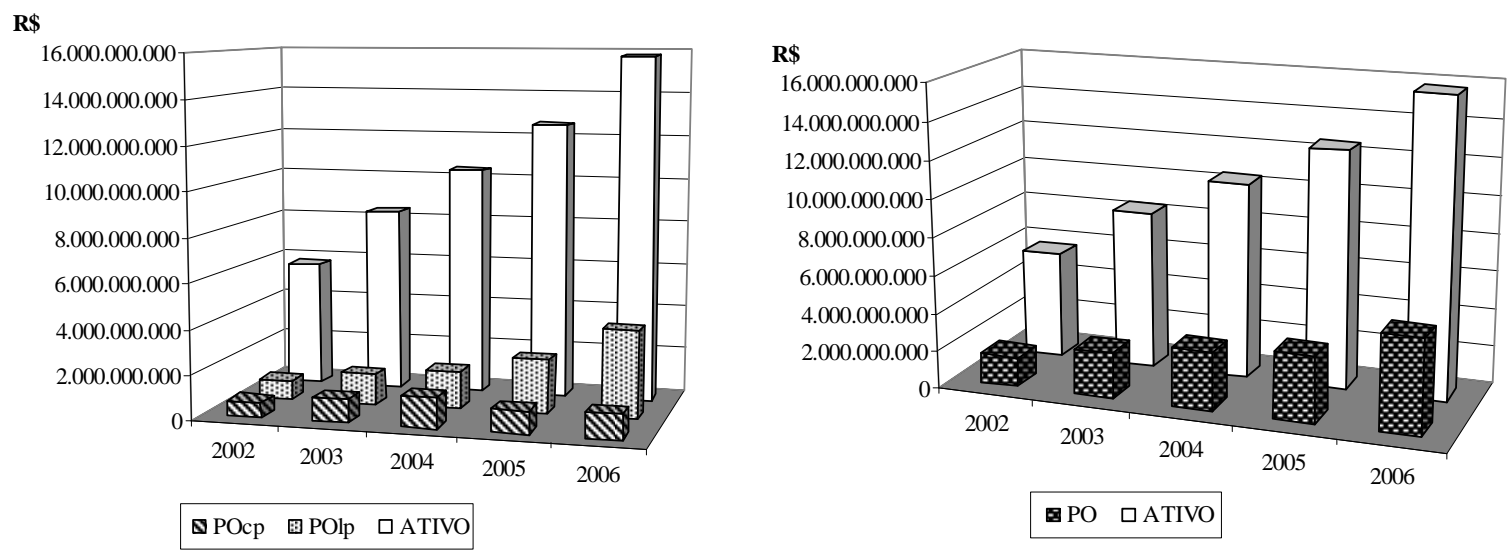

Figura 3 - Evolução do ativo total e passivos onerosos

Alguns pontos que podem ser observados na Figura 3 é a redução da utilização de passivos onerosos de curto prazo no final do período, o crescimento constante do passivo oneroso de longo prazo e do ativo total e a pequena proporção de dívidas em relação ao ativo total, o qual evidencia um grande crescimento das empresas no período.

A Tabela 8 apresenta os níveis médios de endividamento total, de curto prazo e de longo prazo para cada ano analisado.

Tabela 8 - Níveis médios de endividamento

\begin{tabular}{l|c|c|c|c|c|c}
\hline & $\begin{array}{c}\text { Número de } \\
\text { empresas }\end{array}$ & $\mathbf{2 0 0 2}$ & $\mathbf{2 0 0 3}$ & $\mathbf{2 0 0 4}$ & $\mathbf{2 0 0 5}$ & $\mathbf{2 0 0 6}$ \\
\hline Total - PO/A & 35 & 0,258 & 0,427 & 0,332 & 0,288 & 0,281 \\
Curto Prazo - POcp/A & 35 & 0,108 & 0,107 & 0,115 & 0,100 & 0,108 \\
Longo Prazo - POlp/A & 35 & 0,150 & 0,319 & 0,217 & 0,188 & 0,173 \\
\hline
\end{tabular}

Legendas:

PO/A: relação entre o Passivo Oneroso e o Ativo

POcp/A: relação entre o Passivo Oneroso de Curto Prazo e o Ativo

POlp/A: relação entre o Passivo Oneroso de Longo Prazo e o Ativo.

Verifica-se que, em média, as usinas apresentaram um nível de endividamento total em torno de $30 \%$, exceto para o ano de 2003 , onde é possível notar um índice médio de endividamento de longo prazo muito acima dos demais. Neste ano, uma das usinas da amostra, a usina Decasa, apresentou um índice POcp/A igual a zero e um índice POlp/A igual 
a 5,46, o que acabou comprometendo a análise. Caso esta usina fosse desconsiderada neste ano, o índice médio POlp/A seria de 0,142 e o índice médio PO/A seria de 0,253, níveis de endividamento próximos dos demais.

Os financiamentos de longo prazo foram os mais representativos, o que pode ser atribuído à diversidade de linhas de longo prazo disponibilizadas pelo BNDES e muito utilizadas pelo setor sucroalcooleiro, como as linhas provenientes do FINAME e FINEM, além da expressiva participação do PESA no período e de operações de Pré-pagamento. Apesar de não ser possível afirmar que as usinas analisadas utilizaram a estratégia de baixa alavancagem, os números encontrados para a presente amostra evidenciam níveis de endividamento em termos absolutos não muito expressivos e praticamente constantes.

\subsection{Análise do nível de liquidez}

Além da estratégia de baixo endividamento, buscou-se identificar se as usinas utilizaram a estratégia de alta liquidez como tentativa de compensação de juros passivos com juros ativos. A Figura 4 apresenta a evolução da somatória dos grupos Ativos Financeiros e Passivos Onerosos e também a evolução das médias dos índices de endividamento e liquidez.
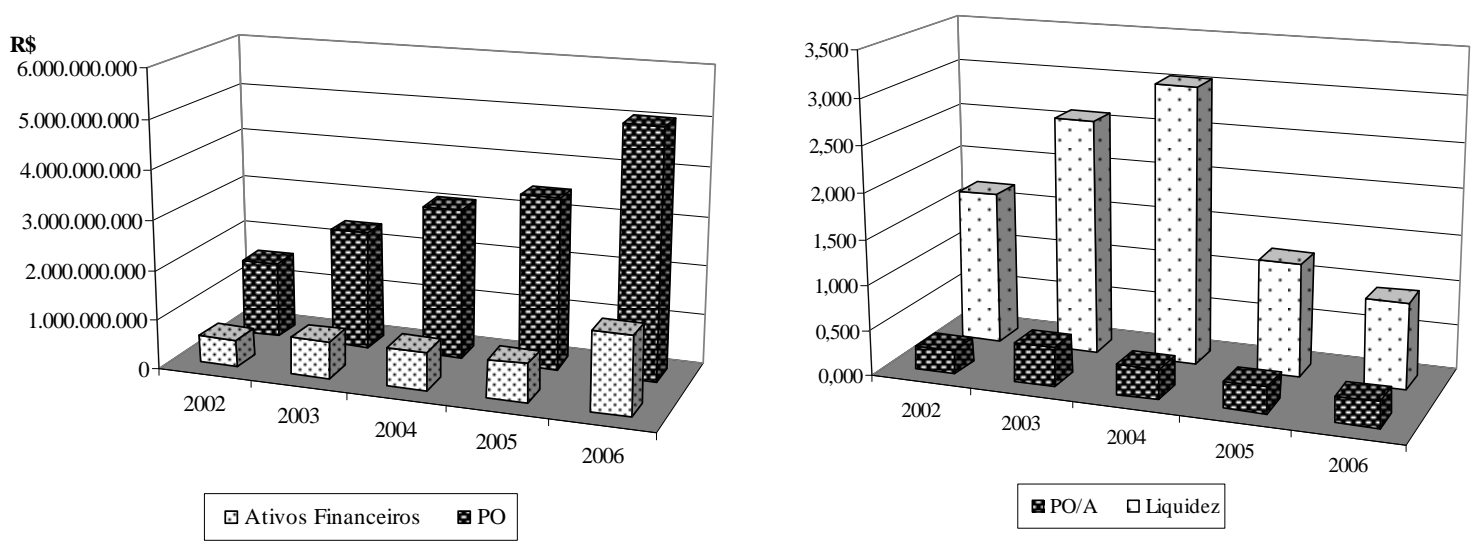

Figura 4 - Evolução dos ativos financeiros, passivos onerosos, endividamento e liquidez

Não é possível afirmar se há uma relação positiva entre os ativos financeiros e os passivos onerosos, visto que, pela somatória, há mudanças nos níveis destes grupos ao longo do período. No entanto, observa-se um grande aumento da liquidez até 2004, período em que vigoraram altas taxas de juros, e uma redução brusca em 2005 e 2006.

Ao voltar para uma análise dos dados verifica-se que as usinas Furlan, Santa Adélia e Alcoeste apresentaram índices de liquidez muito altos neste período gerados por um valor muito pequeno de passivos onerosos, o que comprometeu a análise dos índices médios de liquidez. Caso estas empresas fossem desconsideradas na análise, o índice médio de liquidez no período estaria em torno de 0,49. A Tabela 9 apresenta os níveis médios de liquidez calculados para as 35 usinas da amostra e também para 32 usinas, excluindo as usinas mencionadas.

Tabela 9 - Níveis médios de liquidez

\begin{tabular}{l|c|c|c|c|c|c}
\hline & $\begin{array}{c}\text { Número de } \\
\text { empresas }\end{array}$ & $\mathbf{2 0 0 2}$ & $\mathbf{2 0 0 3}$ & $\mathbf{2 0 0 4}$ & $\mathbf{2 0 0 5}$ & $\mathbf{2 0 0 6}$ \\
\hline At. Fin./PO & 35 & 1,694 & 2,598 & 3,052 & 1,247 & 0,939 \\
\hline At. Fin./PO & 32 & 0,559 & 0,426 & 0,536 & 0,541 & 0,401 \\
\hline
\end{tabular}

Legenda:

At. Fin./PO: relação entre os Ativos Financeiros e o Passivo Oneroso. 
Ao analisar os indicadores médios para as 32 usinas da amostra é possível notar que a sua evolução acompanha a evolução da taxa DI no período, como pode ser observado na tabela 1, o que evidencia a possibilidade de utilização da estratégia de alta liquidez pelas usinas. No entanto, como em relação à estratégia de baixa alavancagem, não é possível afirmar com exatidão se a estratégia de alta liquidez fora utilizada, devido à diversidade de fatores que podem influenciar no processo decisório das empresas. Apesar disto, os resultados obtidos, como altos níveis de liquidez, podem apontar para uma vantagem na utilização do mercado financeiro como alternativa de investimentos e possibilidade de ganhos para as empresas.

\section{CONSIDERAÇÕES FINAIS}

O presente estudo analisou a composição do endividamento de usinas de açúcar e álcool da região centro-sul do país e verificou se as estratégias de baixo endividamento e/ou alta liquidez foram utilizadas por elas como tentativa de compensar as altas taxas de juros a que estavam sujeitas no mercado financeiro nacional. Para a análise da composição do endividamento, as linhas de financiamento encontradas em notas explicativas foram agrupadas em quatro categorias: linhas diferenciadas em moeda nacional (1N), linhas diferenciadas em moeda estrangeira (1E), linhas de mercado em moeda nacional $(2 \mathrm{~N})$ e linhas de mercado em moeda estrangeira (2E).

Como principais resultados têm-se que, no período analisado, as usinas utilizaram em primeiro lugar recursos provenientes de linhas diferenciadas em moeda nacional (38\%) e em segundo lugar recursos provenientes de linhas de mercado em moeda estrangeira (37\%). Este resultado se justifica pelo fato de estas linhas oferecerem taxas de juros mais atrativas e constituírem uma alternativa para as empresas fugirem das altas taxas de juros das linhas de mercado em moeda nacional, as quais ficaram em terceiro lugar com apenas $23 \%$ de participação no endividamento.

Verificou-se também que, em média, as usinas apresentaram um nível de endividamento em torno de $30 \%$, prevalecendo a captação de recursos de longo prazo, e altos níveis de liquidez ao longo do período. No entanto, não é possível afirmar com precisão se elas utilizaram as estratégias de baixos níveis de alavancagem e/ou manutenção de alta liquidez, visto a diversidade de fatores que influenciam o processo de tomada de decisão das empresas. Apesar disto, os números encontrados para a amostra analisada evidenciam níveis de endividamento não muito expressivos e praticamente constantes, além de altos níveis de liquidez, o que pode apontar para uma vantagem na utilização do mercado financeiro como alternativa de compensação de juros passivos com juros ativos pelas empresas.

Também foi possível verificar que a maior utilização de recursos de longo prazo é devida à disponibilidade de linhas do BNDES, à participação significativa do Programa Especial de Saneamento de Ativos (PESA) no passivo oneroso e às operações de Prépagamento, o que possibilitou alongar o financiamento das usinas analisadas.

Considera-se que a principal contribuição da pesquisa foi a inclusão de aspectos relacionados a características institucionais brasileiras para a análise da estrutura de capital das usinas pertencentes à amostra, como a existência de fontes e linhas diferenciadas de financiamento. A possibilidade de utilização destas linhas influenciou as decisões de captação de recursos tomadas pelas empresas, visto que seu uso prevaleceu em todos os anos, fato que ajuda a ratificar a importância da incorporação de fatores institucionais na análise da estrutura de capital das empresas.

Algumas das limitações deste trabalho podem ser atribuídas à qualidade das demonstrações contábeis das usinas brasileiras de açúcar e álcool. Muitas vezes, estas demonstrações divulgam apenas o mínimo exigido pela legislação, tornando impossível a 
realização de algumas análises ou a visualização detalhada de alguns grupos patrimoniais. Não foi possível, por exemplo, analisar a composição do endividamento de curto e longo prazo, mas apenas do endividamento total, visto que a maior parte das usinas apresentava apenas o detalhamento da somatória dos grupos Empréstimos e Financiamentos de curto e longo prazos.

Também não foi possível utilizar todas as usinas existentes no banco de dados do Observatório do Setor Sucroalcooleiro, visto que nem todas apresentavam o detalhamento de seus empréstimos e financiamentos para que fosse possível a classificação das linhas de financiamento dentro das quatro categorias analisadas.

Pretende-se em trabalho futuro, em continuidade a este apresentado, analisar os fatores determinantes da estrutura de capital das usinas analisadas incorporando ao estudo os diferentes tipos de linhas de financiamento $(1 \mathrm{~N}, 1 \mathrm{E}, 2 \mathrm{~N}$ e $2 \mathrm{E})$ com o intuito de verificar a influência do acesso a estas diferentes fontes de recursos sobre as decisões de estrutura de capital destas empresas.

\section{REFERÊNCIAS}

ASSAF NETO, A. Finanças corporativas e valor. 2. ed. São Paulo: Atlas, 2006.

BARCLAY, M. J.; SMITH Jr, C. W. The maturity structure of corporate debt. The Journal of Finance, v. 50, n. 2, p. 609-631, Jun. 1995. http://dx.doi.org/10.2307/2329421

BOOTH, L.; AIVAZIAN, V.; DEMIRGÜÇ-KUNT, A.; MAKSIMOVIC, V. Capital structures in developing countries. The Journal of Finance, v. LVI, n. 1, p. 87-130, Feb. 2001. http://dx.doi.org/10.1111/0022-1082.00320

BRITO, G. A. S.; CORRAR, L. J.; BATISTELLA, F. D. Fatores determinantes da estrutura de capital das maiores empresas que atuam no Brasil. Revista Contabilidade \& Finanças USP, São Paulo, v. 18, n. 43, p. 9-19, jan./abr. 2007.

FAULKENDER, M.; PETERSEN, M. A. Does the source of capital affect the capital structure? The Review of Financial Studies, New York, v. 19, n. 1, p. 45-79, 2006. http://dx.doi.org/10.1093/rfs/hhj003

GUEDES, J.; OPLER, T. The determinants of the maturity of corporate debt issues. The Journal of Finance, v. 51, n. 5, p. 1809-1833, Dec. 1996. http://dx.doi.org/10.2307/2329539

JENSEN, M. C.; MECKLING, W. H. Theory of the firm: managerial behavior, agency costs and ownership structure. Journal of Financial Economics, v. 3, n. 4, p. 305-360, Oct. 1976. http://dx.doi.org/10.1016/0304-405X(76)90026-X

MARTINS, G. A. Manual para elaboração de monografias e dissertações. 3 ed. São Paulo: Atlas, 2002.

MODIGLIANI, F.; MILLER, M. H. The cost of capital, corporation finance and the theory of investment. The American Economic Review, v. 48, n. 3, p. 261-297, Jun. 1958.

MODIGLIANI, F.; MILlER, M. H. Corporate income taxes and the cost of capital: a correction. The American Economic Review, v. 53, n. 3, p. 433-443, Jun. 1963.

MYERS, S. C. Determinants of corporate borrowing. Journal of Financial Economics, p. 147-175, Jul. 1977. http://dx.doi.org/10.1016/0304-405X(77)90015-0

MYERS, S. C. The capital structure puzzle. The Journal of Finance, v. 39, n. 3, p. 575-592, Jul. 1984. http://dx.doi.org/10.2307/2327916

MYERS, S. C. Capital structure. The Journal of Economic Perspectives, v. 15, n. 2, p. 81102, Spring 2001. 
MYERS, S. C.; MAJLUF, N. S. Corporate financing and investment decisions when firms have informations that investors do not have. Journal of Financial Economics. v. 13, n. 2, p. 187-221, 1984. http://dx.doi.org/10.1016/0304-405X(84)90023-0

RAJAN, R. G.; ZINGALES, L. What do we know about optimal capital structure? Some evidence from international data. The Journal of Finance, Chicago, v. 50, n. 5, p. 14211460, Dec. 1995.

STOHS, M. H.; MAUER, D. C. The determinants of corporate debt maturity structure. Journal of Business, Chicago, v. 69, n. 3, p. 279-312, 1996.

TERRA, P. R. S. Estrutura de capital e os fatores macroeconômicos na América Latina. Revista de Administração da Universidade de São Paulo, São Paulo, v. 42, n. 2, p. 192204, abr./jun. 2007.

TITMAN, S.; WESSELS, R. The determinants of capital structure choice. The Journal of Finance, v. 43, n. 1, p. 1-19, Mar. 1988. http://dx.doi.org/10.2307/2328319

VALLE, M. R. Estrutura de capital de empresas brasileiras num ambiente de altas taxas de juros e na presença de fontes diferenciadas de financiamento. 2008. $104 \mathrm{f}$. Tese (Livre Docência) - Departamento de Contabilidade, Faculdade de Economia, Administração e Contabilidade de Ribeirão Preto, Universidade de São Paulo, Ribeirão Preto, 2008. 